\title{
Swedish Belief Narratives on Afterlife Earlier and Today*
}

\author{
Anders Gustavsson \\ University of Oslo, Oslo, Norway \\ Email: anders.gustavsson@ikos.uio.no \\ Received 15 October 2014; revised 15 November 2014; accepted 22 November 2014 \\ Copyright (C) 2014 by author and Scientific Research Publishing Inc. \\ This work is licensed under the Creative Commons Attribution International License (CC BY). \\ http://creativecommons.org/licenses/by/4.0/

c) (i) Open Access

\begin{abstract}
My aim is to examine afterlife beliefs in Sweden, partly from the late 1800s and the early 1900s, partly from the 2000s. It will be a contrastive study of two different periods and not a diachronic study of developments across a continuous stretch of time. Since this is a study of popular beliefs, ordinary people are in the center. My research questions are: What types of popular beliefs can be traced in the pre-industrial society? What types of beliefs are characteristic of the present-day society? Which differences and similarities can be found in belief narratives of these periods? How can scholars get information about belief in afterlife in older times and nowadays? In the 1800s this is documented through narratives in folklore archives and inscriptions on grave memorials, nowadays - by means of memorial websites on the Internet.
\end{abstract}

\section{Keywords}

Belief Narratives, Folklore Art, Angels, Grave Memorials, Memorial Websites

\section{Introduction}

\subsection{Questions}

My aim is to examine afterlife beliefs in Sweden, partly from the late 1800s and the early 1900s, partly from the 2000s. It will be a contrastive study of two different periods and not a diachronic study of developments across a continuous stretch of time. Since this is a study of popular beliefs, ordinary people are in the center. My research questions are:

What types of popular beliefs can be traced in the pre-industrial society?

"This text was presented and discussed at the international conference in Turku, Finland, 22-24 October 2014, with the theme Images of Afterlife. 
What types of beliefs are characteristic of the present-day society?

Which differences and similarities can be found in belief narratives of these periods?

\subsection{Method and Materials}

How can scholars get information about belief in afterlife in older times and nowadays? In the 1800s this is documented through narratives in folklore archives and inscriptions on grave memorials, nowadays - by means of memorial websites on the Internet.

The Swedish folklore archives contain much information about the rituals and beliefs related to death and burial. It is largely provided by answers to free recordings made without questionnaires and collected during the first part of the 1900s. The majority of respondents were born in the latter part of the 1800s and told about this time. They came mainly from rural areas where most people lived in the late 1800s. My material relates to different parts of Sweden as I examined the archives in Gothenborg (DAG, IFGH, VFF), Lund (LUF) and Uppsala (ULMA).

\section{Beliefs in the Pre-Industrial Society}

According to the folklife records, people in older times hardly had clear ideas about the existence of the dead without their connections to the survivors who were left behind. Thus the recorder Johan Kalén, active in the province of Halland, wrote in 1928: "it is difficult to obtain evidence on ideas of the imagined life on the other side of death” (IFGH, 1305, p. 89). In contrast, people at that time were keen on finding hints of an impending death in their near surroundings. The records provide rich evidence on various forms of such premonitions which made people afraid. Johan Kalén also noted in 1928: "that the dead are able to reveal themselves to the living is a general folkbelief still today”.

\subsection{Soul and Body}

The informants provide a belief that people had a clear idea of the man as a being which consists of body and soul. At the moment of death the soul separated from the body. The soul was imagined to be related to the heart and blood. When the heart ceased to beat, the soul left the body and went away. This could be seen in the form of a candle flame, smoke, a gust of wind or a bird observed at the moment of death. One concrete way to help the soul to leave the body was to open the fireplace damper up to the chimney. A communicator born in 1848 stated in 1926: "In several places, I have heard that they opened the fireplace damper so that the spirit would go away” (IFGH, 751, p. 34, Östra Frölunda, Västergötland). Thus the soul was not just immaterial, but had also a sort of tangible component.

\subsection{Hints of a Blessed or Unblessed Death}

The records evidence a widespread belief that there was a double exit from the earthly life; one could arrive either to a good or evil existence, called blessed and unblessed respectively. The survivors were keen on trying to get a hint if the deceased had been blessed or not. One method of getting it was to listen to the sound of church bells immediately after the death, or at the funeral. If the sound was bright, it was considered as a sign that the dead had been blessed, but a dull sound indicated an unblessed death (IFGH, 5166, p. 18, Vessige in the province of Halland).

Birds who appeared at the time of death could give an idea of where the dead had arrived. A dove suggested a blessed death whereas a raven, magpie or owl an unblessed death. One informant born in 1861 in Stora Lundby in the province of Västergötland told in 1928: "If a raven appeared and sat on the coffin, when the deceased was carried to the grave, this was a sign that the deceased went to hell. The raven was perceived as the devil's bird, and the dove was God's bird” (IFGH, 1579, p. 30). The deceased's appearance could also give hints. A smile on the lips indicated a blessed death, whereas a contorted face meant an unblessed death (IFGH, 1730, p. 17, Rölanda in the province of Dalsland).

At a good death angels could appear before or at the moment of death. An informant from Åmål in the province of Dalsland born in 1868 told in 1934 about his father's near-death experience and death shortly afterwards: "It was a few days before my father would die. Then he said one evening as we sat near him at his bedside: You can never believe how lucky I'm feeling. I saw an angel coming and taking me, and everything 
was so beautiful where we came. They sang so beautifully for us. So now it's not long until I will pass away. It was only a few days before he died. If any be blessed, he must be the one" (IFGH, 3525, p. 41). At the moment of death, angels were considered to retrieve the deceased to be blessed. An about 70-year-old informant from Skellefteå in the province of Västerbotten told in 1929: "If in the moment of death the bell ringing was heard and it was not natural, then it was a certain hint that the dead had been blessed. There were angels who took him away" (ULMA, 2706: 9, p. 4). However, angels are not mentioned as frequently as the sound of church bells and birds at the moment of death.

\subsection{Beliefs on the Meaning of Bliss and Unhappiness}

\subsubsection{Afterlife Bliss}

Thoughts of a good afterlife existence with God and Jesus are only characteristic of explicit Christians, such as the singer Fina Gren (1862-1957) or among members of free churches. Narratives of this type are largely lacking in the folklife records. However, they are found in chapbooks and interview data from members of free churches. They openly talked about their religious faith ([1], p. 196f). In this context it should be mentioned that the recorders in older time separated the religious belief from folkbelief and therefore did not ask about it ([1], p. 9, 174f). This suggests that certain beliefs about heaven and hell might have been more widespread than the folklife records show it.

The itinerant singer Fina Gren wrote in her hand-written songs about "God's paradise”, "winning the crown”, "streets of gold" etc. which is in accordance with Christian preaching that she had heard in the churches during her wanderings. One verse reads: "Yes, God grant me that I soon be blessed in heaven, reaching the blessed goal one day; then I would play the harp and sing my new song".

The farmer, churchwarden and writer of diaries Jakob Jonsson (1795-1879) in Röra parish in the province of Bohuslän did not write about his death until the end of his life [2]. "In this as in all my other affairs, I deliver myself into the hands of the Blessed Father. He shall dispose of me as He pleases". After his death, a handwritten song with five verses was hung on the wall in his home. Its verses were written in the first person, the newly deceased Jonsson speaking in the I-form and committing his soul into God's hands. "As if borne by the wings of angels", the soul rises "free and joyful" up to Heaven which is described as a "beautiful city" full of "sweet peace". There the deceased shall meet those that have died before, and his body shall be renewed on the Day of Judgement.

Also, some inscriptions or references to hymns on grave memorials in the 1800 s describe how the deceased long to come to a blissful heavenly existence [3]. In Fiskebäckskil in the province of Bohuslän, a text from the 1819 hymn book was inscribed in 1827 on the limestone gravestone of the wife Maria Brita (see Figure 1). This text emanates safety as Jesus guards and cares for the grave while her remains rest there. The soul is not there as it is already resting in happiness with Jesus. Thus, a radical contrast between the body lying down in the grave and the soul far away is manifest.

A limestone tombstone in Torp in Bohuslän is dated to 1847. It was erected over the wife Christina Olsdaughter from a small farm Rödstegen who died of cold 48 years old (see Figure 2). The text from hymn 482: 6 in the 1819 hymnal reads: "God be praised! I reached the harbor, for a little time here I toiled and I got peace and consolation in the grave, and here God unites us again". The deceased who speaks in the first person contrasts the difficulties she had in her earthly life with the bliss she experienced after her death when she "reached the harbor" and got peace and consolation in the face of God. The word harbor implies that the existence after death is seen as the aim of life. It is notable that in case cast-iron crosses have space for a pictorial symbol in the lower part, this is often a winged angel, which can be related to a positive vision of afterlife (see Figure 3).

Although the folklife records do not expand on what the blessed existence looked like, there is some data on meetings with the deceased which their descendents could experience. To these positive contacts belonged the belief that the deceased were able to send messages to the living with the help of a bird. Birds were important messengers in contacts with the invisible world. Mothers who died could appear to help their children when they got into trouble. A female communicator, born in 1861 from Hjälmseryd in the province of Småland, told in 1931 about two young children who lost their mother and their father remarried. The stepmother treated the children badly and they were frozen and starving. They went to their mother's grave and wept. The dead mother then appeared before the stepmother with a rhyme: "be you a mother so kind, you will be blessed in heaven, but be you a mother so evil, you will suffer much coersion in hell”. Thereupon the kids got a better care (LUF M, 3079, p. 33f). 


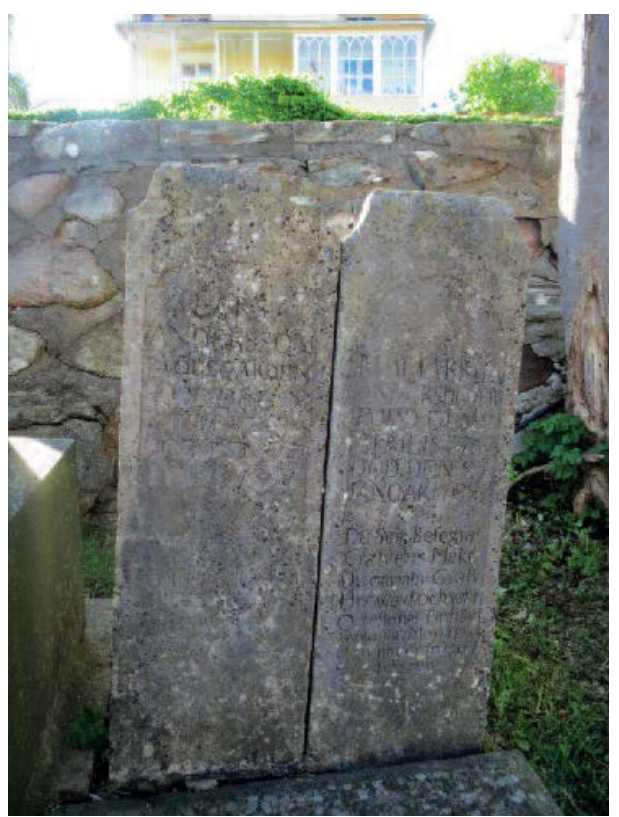

Figure 1. Two separate limestone gravestones standing side-by-side in Fiskebäckskil. The stone to the right commemorates the wife Maria Brita (1767-1827). A text from the 1819 hymnal is inscribed on her stone.

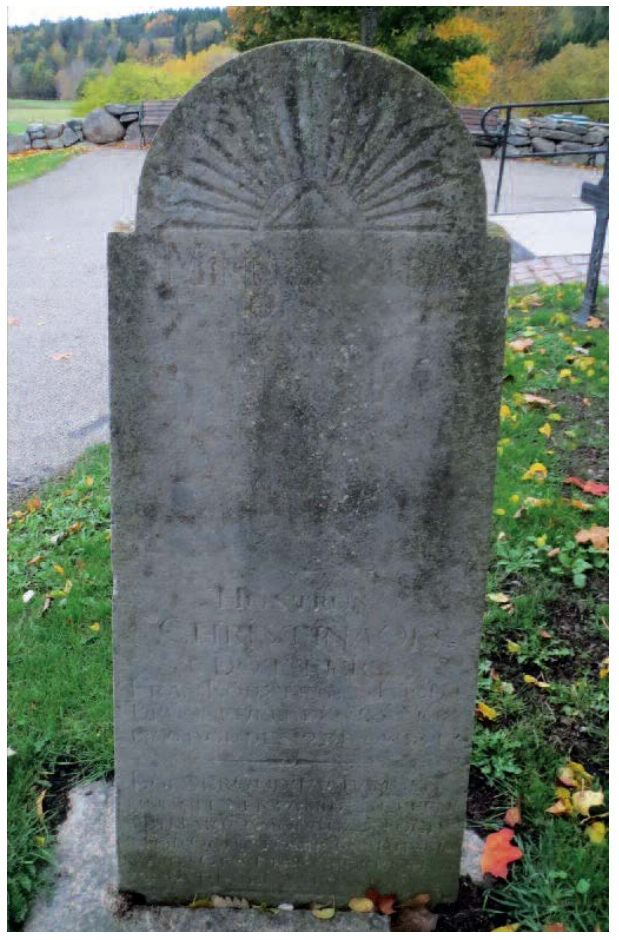

Figure 2. A narrow, rounded limestone gravestone with a radiant triangle on its top commemorating the wife Christina Olsdaughter from a small farm in Torp who died of cold in 1847, 48 years old. 


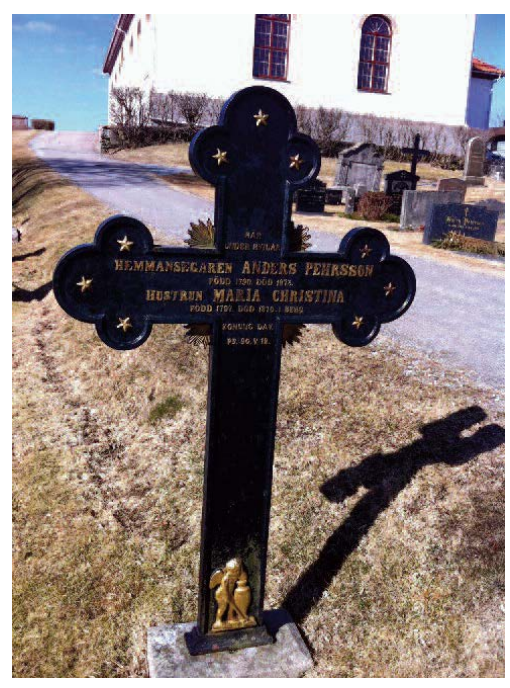

Figure 3. A cast-iron cross from Myckleby dated to 1875 . Three stars decorating each arm and the top symbolize light. A winged angel decorates the foot.

\subsubsection{The Unblessed Existence}

According to the records, it is obvious that the unblessed existence was miserable. However, there are only a few stories about a specific place such as hell with the devil as a tormentor. An informant born in 1905 in Ragunda in the province of Jämtland heard in his youth of the "club of hell". "It would torment those who because of their sins had come to the devil. The club was made of a human cranium whose contents consisted of a curious mixture of flowing iron and burning sulphur. It was part of the daily routine in the hell that flogging was performed with such clubs” (ULMA, 27348, p. 20).

According the folklife records, people were most afraid of evil meetings with the disquieted spirits of dead people known as ghosts. Because of their previous living they had no peace in the grave where the body lay. Sinister meetings with ghosts are mentioned far more often than meetings with those who were blessed after death. This suggests that the fear of evil meetings was something you lived with and were afraid of. Along the coasts the ghosts of people who had died at sea and were not given a Christian burial were named specters (see Figure 4). They could be heard screaming in the night. These beings were considered to be especially dangerous for those searching for sunken wreck ships. Ghosts that had lost their clothes felt the cold of bad weather. Thus, a ghost depicted by the folk-life artist Carl Gustaf Bernhardson (1915-1998) in the form of a naked skeleton was walking around and crying: "I want my coat back. The north wind is blowing and I'm freezing".

Bernhardson has made a unique contribution to folklore with his portrayals of images which people in past times had of supernatural beings. He had the ability to transform immaterial conceptions of belief into visual images. He believed in the existence of beings which he painted and could attest to having seen them. He had, in other words, a second sight as he happened to have an experience of visions of a world different from that which can be seen with ordinary eyes. He maintained that he had met dead people and recognized them. On a bicycle tour in 1979, in broad daylight, he met a headless woman who had been dead for several years, but as the artist told "when I looked up again, she had disappeared" [4].

The ghosts caused terror among people. An informant from Erska in the province of Västergötland born in 1868 told: "I remember that people were so afraid that they would see such a ghost in the night" (IFGH, 4953, p. 8). Ghosts could be a danger for the deceased's former enemies in life. So, it was important for all enemies to be reconciled before any of them died. One informant from Augerum in the province of Blekinge born in 1857 told in 1931: "If someone was dying, his enemies were asked to come so that they could be reconciled. Otherwise the dead revenged on adversaries. He had no peace in the grave. One person got hurt by the dead who had enemies here on earth. People were sure of that. Directly after the funeral, the deceased visited his enemies. ...They were harassed by the deceased as soon as they were out in the darkness” (LUF M, 3196, pp. 1-2, 5). 


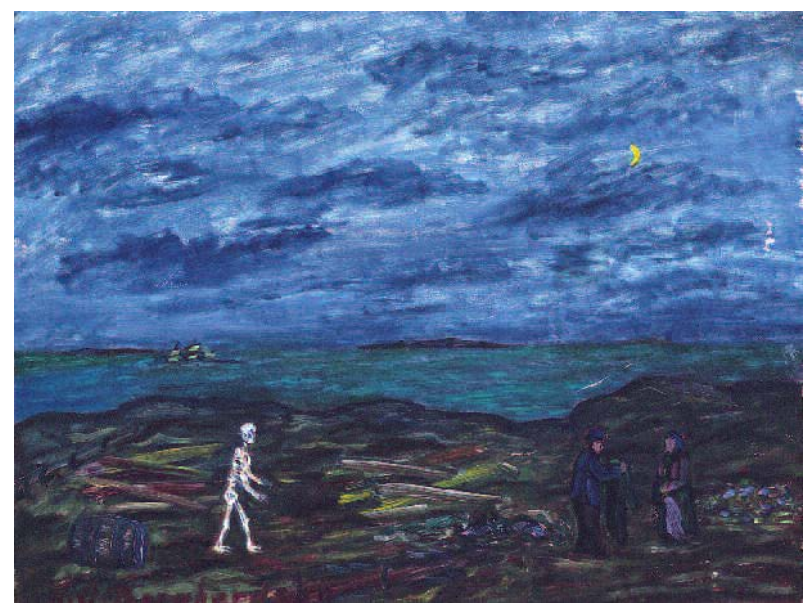

Figure 4. A ghost of the little island of Gåsö cries that he is freezing and wants his clothes back, to the dismay of the man and the woman standing to the right. Painting by Carl Gustaf Bernhardson. Bohuslän Museum, Uddevalla, No. 225.

People tried to protect themselves against ghosts by using protective agents that were common in traditional folklore. It was important to obtain such protection as this is mentioned in a great number of records. People sprinkled flaxseed, ash or salt just after death and around a funeral. This way the deceased who were likely to become ghosts could be prevented as they had to pick up all the seeds on the night before the sunrise. Then they had to return to their graves (IFGH, 740, p. 86, Böne in the province of Västergötland). Another way of protecting against ghosts was described by an informant born in 1862 in Seglora in the province of Västergötland: "People sprinkled burnt seed or corn on the road and said, 'Now, you will not go over here before this seed grows up”” (IFGH, 4602, p. 35). It would be as difficult as possible for ghosts to come.

\subsection{Connection between the Earthly and Future Life}

The folklife records evidence that the existence after death is imagined similar to that of earthly life in highly concrete terms. People seem to be unable to think of it differently from what they were used to. This being so, objects were placed in the coffin in the way the deceased were thought to need these things, no matter whether they had died blessed or unblessed. In some cases, the deceased earlier expressed wishes about what they wanted to have in the coffin for the use in their future existence. These could be money, clothes, glasses, work tools, and food. An expression about money in the coffin from Krogsered in the province of Halland reads: "He shall have with him so much that he can do the right thing where he arrives” (IFGH, 1305, p. 74).

A criterion for the selection was that the deceased would have objects in the coffin which they particularly liked in their earthly life. Women could wish their finest clothes. One informant born in 1855 in Eskilsäter in the province of Värmland told in 1928 about a woman whose will was "to be beautifully dressed when she died, with her rings on the fingers, as she believed that this is how she would be clad after her death" (IFGH, 1224, p. 1). Men who were addicted to alcohol could have a bottle of spirits. Those who used snuff or pipe got a filled snuff box or a pipe of tobacco with them.

These gifts in the coffin would not only be helpful after death; thanks to them there would be no reason for the deceased to live a ghostly life, walking around and picking up things which they might need in the afterlife, such as, for instance, their snuffbox. One informant from Naverstad in the province of Bohuslän told in 1920 that leaving gifts in the coffin "was practised as late as 30 years ago" (VFF, 165, p. 1). That suggests that this practice could last till the late 1800s. Other informants maintained that it no longer existed during the early 1900s, but could be observed during their parents' generation. Bottles of spirits, snuff boxes and pipes with tobacco have actually been found in cemeteries at renewed excavations in earlier graves. This has been mentioned in several records by sextons. When sextons and other men found bottles of spirits, they emptied those up. The father of an informant, born in 1870 in Daretorp in the province of Västergötland, was a gravedigger. This is what he told in 1945: 
Per i Knäppet was a gravedigger before my father. When he dug a grave at a stone wall, he found a bottle of brandy. He and another man sat on the stone wall and drank it up. The bottle was earlier put in the coffin of the deceased. My father dug up many old pipes, snuff and tobacco boxes (IFGH, 5043, p. 23).

That life on the other side of death recalled the earthly life is evident in one of the folk-life artist Carl Gustaf Bernhardson's records. A man born in 1860 related how he once dreamt that he had seen another man whom he knew but who had been dead for several years. "He was just like he used to be. ...So I thought I'd ask him if he was happy up there. He said: 'You can't imagine how good it is. And no one has to do very much either. I just go outside every day and gather spruce cones. That's all I do, so everything is always just fine’” (IFGH, 6194: 2).

\section{Beliefs during the 2000s}

After examining images of afterlife in Sweden in the preindustrial society during the last part of the 1800s, I turn my focus to the 2000s. Research on material obtained from the Internet has begun to attract attention of cultural scientists during the 2000s. This is seen in, inter alia, articles in the annual Ethnologia Scandinavica [5] from 2009 which discuss questions related to the use of the Internet as a research source. Of interest is also the anthology Digital Storytelling edited by the Norwegian sociologist Knut Lundby in 2008 [6]. International Society of Ethnology and Folklore (abbr. SIEF) published the anthology Shaping Virtual Lives in 2012 [7]. The term "Netnography" is emerging ([8], p. 60).

In this new research situation I decided to study memorial sites on the Internet. These are a new form of expressing grief and memories about the deceased relatives and friends. Since the messages and imaginary conversations are published on the Internet, they are also accessible to outsiders, acquaintances as well as strangers, including scholars. In my sample of such websites, I have studied those that are open to the public. I have avoided those that are available only to a limited circle or those which require the guest to log on.

Memorial sites have undergone an explosive development during the 2000s. In 2008, there were about 600 websites of this type in Sweden [9]. My research deals with websites that became available during 2009 and 2010 in Norway and Sweden, with the bulk of material from Sweden ${ }^{1}$. These websites were set up by people who had recently suffered an extreme grief in their immediate relationships. The focus of my analysis is on the contents of messages which stress a faith perspective. My research questions here are:

What concepts of afterlife are expressed?

What does the afterlife status of the deceased look like?

Is any form of dialogue with the deceased considered to be possible?

Is any form of future reunion with the deceased believed to be possible?

\subsection{Afterlife in Heaven}

The concept that the deceased come to heaven is common. There they can meet those who have died earlier. A new fellowship is believed to take place after death. The existence in heaven is considered to be very similar to that on earth. It is conceptualized as a highly pleasant life in very concrete terms. Thus the deceased are believed to be able to continue practicing in heaven their usual activities. This can be a motocross which Marcus, who died in 2008 at 23 years of age, loved so much. A message about him says: "We hope that you're happy there among the angels and do a lot of motocross racing”.

You never meet negative concepts of the existence in heaven. This seems to reflect neo-religious ideas of "the recaptured paradise” [10] [11]. In spite of increasing secularization, doubt and a clear denial of any form of existence after death are very rare in the memorial messages. Our concepts of afterlife existence can change when a sudden death occurs in our own immediate circle. It seems impossible to believe that everything has come to an end. This is especially true with regard to deaths of children and young people. This new turn in ideas about afterlife is manifest in the messages expressed by the mother of Max and Saga who were murdered in 2008:

I have never been a believer. Never believed in God and was rather sceptical about the concepts of life after death. But after this... I am still not a believer. But I want to believe that something happens after death. I want to believe that Max and Saga are well and happy and that they are together.

This non-traditional, not Christian belief has come to light in the postmodern, secularized Sweden. It is part of ${ }^{\overline{1}}$ My sources are recorded in 16, p. 161. They were accessed 1 April 2011. 
a conceptual world that the afflicted persons can create themselves in order to find some form of consolation. This type of individualism is characteristic of neo-religious trends [12]. The concept of vernacular religion in everyday life has also been put into practice nowadays [13].

\subsection{Opportunities for Contacts with the Deceased}

The idea that the deceased can be contacted by the living who can even communicate their messages to the deceased on a computer is often expressed in memorial sites. It is believed that the deceased can have a computer. The technical possibilities of this life are thus transferable to the afterlife existence. Also, when the deceased are in heaven, they are often believed to watch over and protect their friends and relatives.

The concept of reunion with the deceased at some time in the future is visible on website messages. In terms of this concept, a new type of existence and fellowship that will never end is possible in afterlife. Finiteness gives place to eternity, and joy is supremely restored. To look forward in this way brings consolation in a state of grief. One explicitly writes about hell or punishment after death only in reference to those who have murdered a loved one close to the message writer.

\subsection{Meetings with Angels and Other Divine Beings in Afterlife}

Angels are often mentioned in site messages. In order to enter their world, the deceased must climb an endlessly long stairway which is depicted in a number of messages (see Figure 5).

The meeting with angels is described in a highly positive context for the deceased. Thus, when Richard died in 2008 at 27 years of age, his cousin Laura wrote: "Your last journey to heaven has taken place and a lot of angels carry you there on their wings”. The deceased can also speak poetically about their happiness of being among angels. This can help to comfort mourners. If angels are presented as beings of a supernatural or divine character, they are described in terms of neo-religious New Age conceptions [11]. In such cases God appears more distant.

There are, however, instances when in addition to angels God and Jesus are mentioned. This is seen as a highly positive factor for the deceased. When the four-month-old Nicolai died, his family wrote: "God had other plans for you. He wanted you to be near him, and you left us in despair about our loss". Another instance is when the deceased is described as a gift or a loan from God.

\subsection{The Deceased as Angelic Beings}

A concept common in the messages is that children and young people become angels after death. This is in striking contrast to earlier beliefs according to which the deceased were supposed to be souls, not angels. The British sociologist Tony Walter has detected the same tendency in England [14]. The mothers of dead children

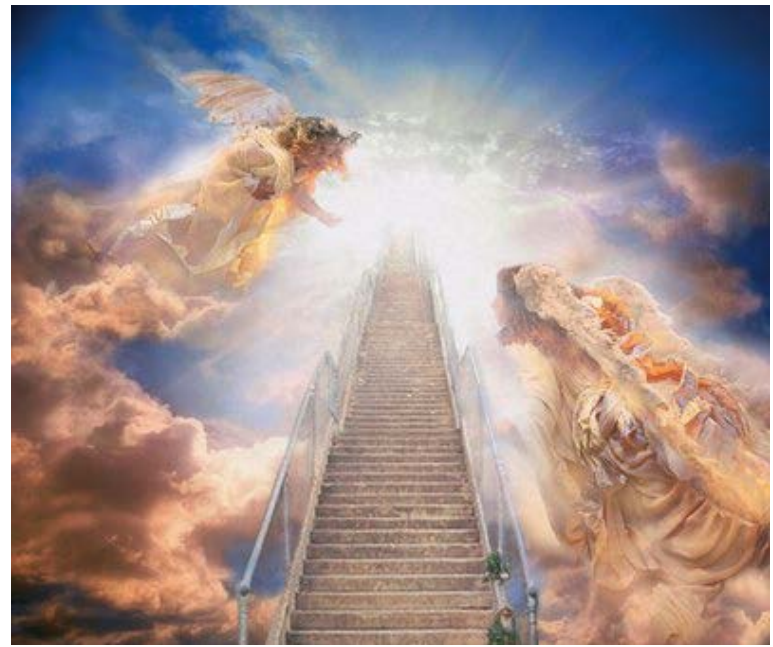

Figure 5. Angels guard the stairs that the dead climb up into heaven [19] 
call themselves "Mothers of Angels" in the Swedish messages. In addition, the deceased are glorified when they are described as the very best, finest or prettiest angels in heaven (see Figure 6).

There are some examples of belief in the deceased already having been an angel while on earth and having acted there as a loan to their relatives and friends. The folklorist Bente Gullveig Alver has shown that earlier conceptions of a guardian angel have changed in modern neo-religiosity; now human beings are believed to receive the angelic wings themselves [15]. Thus the supernatural is relocated onto the individual.

One might expect that only the best individuals could become angels. This is not the case, however. There are messages that speak with regret about drug addiction that brought the deceased (usually young men) to an early death.

\section{Concluding Remarks-Comparisons between Then and Now}

Finally I want to compare characteristics of the folk beliefs of older times and the present. What are differences and similarities between these two historical periods?

Firstly I will look at differences. In older times the folk belief always differentiated between a blessed and an unblessed exit from this life. This, however, cannot be observed in the present-day internet messages. The belief of earlier times has been replaced by exclusively positive ideas about afterlife existence. If we do not believe in the unblessed exit from life, there are no prerequisites for the belief in evil and dangerous ghosts. This may explain why the fear of those who were so threatening in the older material has been replaced by the search of surviving relatives for a close contact with the deceased, instead of protecting themselves against such meetings.

The deceased in the present beliefs watch over and protect their descendants. In earlier times, only those who died a blessed death were believed to perform this positive function; however, they were not mentioned as often as ghosts.

In older times, angels appeared as positive beings in connection with the death of blessed people. The dead man's soul was helped on its way to heaven where it was believed to obtain the new existence. Nowadays the belief in angels is even more prominent, but at the same time it is increasingly disconnected from the traditional Christian belief in angels. New Age inspired [11] beliefs have largely taken over in Sweden, with the help of increasing secularization [16]. Their focus is on the individual to a much greater extent than it was in the earlier conceptual world. This is the premise of the modern belief that the dead become angels after death and, moreover, that they had this status already in their earthly life and then became perfect angels after death. This belief would have been unthinkable in earlier times. Soul was then the central concept; this belief, in many cases, has been replaced of the new belief that the deceased may be angels. So the angel concept has lost its previous religious meaning [17].

The older folklife records hardly maintain that people are expected to get reunited with their deceased relatives after death and thus be together forever. However, such beliefs are expressed in Christian texts in the

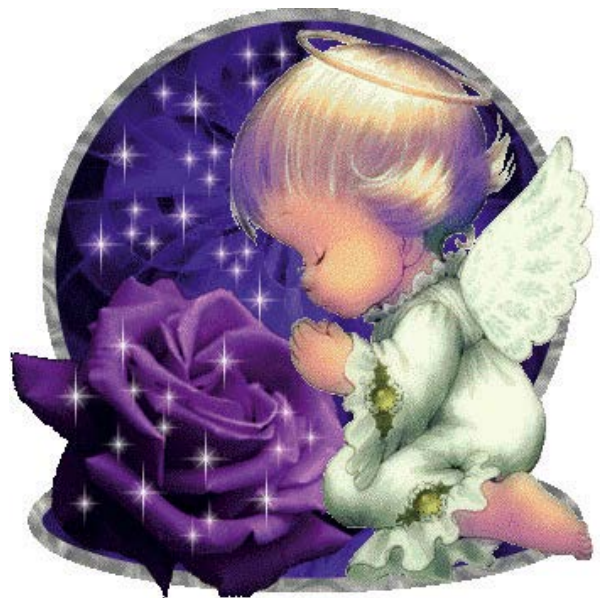

Figure 6. The mother of the deceased daughter has written: "Hugs from your beloved mother". The angel has a halo and wings [20]. 
form of chapbooks, inscriptions on grave memorials as well as in free church songs and interview data. Such faith and hope are also expressed nowadays in contemporary messages on the Internet. The relatives of the deceased who write these messages look forward to this type of eternal existence, even though it will take place in a vague future [18].

So far, the differences between the older and the present times have been emphasized. The most obvious similarity characteristic of these two periods is the common belief in a continued existence after death. This existence is perceived similarly to the earthly life. Thus, in earlier times various objects were placed in the coffin to meet future needs of the deceased; this was also a way to protect the living against ghosts. Nowadays this belief does not take such concrete forms, but a similarity with older times is manifest in memorial messages which presume that the deceased have access to today's new technology. This can apply to a computer which can be used by the deceased when they send and receive messages to and from the survivors. The deceased are also believed to be able to continue running motocross if they had a great interest for that in the earthly life.

\section{References}

[1] Gustavsson, A. (2012) Cultural Studies on Folk Religion in Scandinavia. Novus, Oslo.

[2] Gustavsson, A. (2009) Death in a 19th-Century Peasant Society. In: Folklore. Electronic Journal, 43, 30. http://www.folklore.ee/folklore/vol43/gustavsson.pdf

[3] Gustavsson, A. (2014) Grave Memorials as Cultural Heritage in Western Sweden with Focus on the 1800s. Novus, Oslo.

[4] Gustavsson, A. (2011) The Folk-Life Artist Carl Gustaf Bernhardson. Novus, Oslo.

[5] Palmgren, A.-C. (2009) Bodily Lives in Virtual Worlds. In: Ethnologia Scandinavica, 39, 241.

[6] Lundby, K., Ed. (2008) Digital Storytelling. Peter Lang Publishing Group, Bern and Pieterlen.

[7] Krawcyk-Waasilewska, V., Meder, T. and Ross, A., Eds. (2012) Shaping Virtual Lives. Online Identities, Representations, and Conducts. Lód’z University Press, Lód'z.

[8] Kozinets, R.V. (2010) Netnography. Doing Ethnographic Research Online. Paperback, Los Angeles.

[9] (2008) Minnesplatser på nätet. In: Dagens Nyheter, 6 October.

[10] Alver, B.G. (1999) Paradise Recaptured. Experience, Interpretation and Narrative. In: Folk Religion. Continuity and Change, Universidade Nova, Lisboa.

[11] Kraft, S.E. (2011) Hva er nyreligiøsitet. Universitetsforlaget, Oslo.

[12] Saelid, G.I. and Mikaelsson, L. (2005) Kulturens refortrylling. Nyreligiøsitet i moderne samfunn. 2nd Edition, Universitetsforlaget, Oslo.

[13] Bowman, M. and Valk, Ü, Eds. (2012) Vernacular Religion in Everyday Life: Expressions of Belief. Equinox, Sheffield, Oakville.

[14] Walter, T. (2011) Angels Not Souls: Popular Religion in the Online Mourning for British Celebrity Jade Goody. In: Religion, 41, 29-51. http://dx.doi.org/10.1080/0048721X.2011.553138

[15] Alver, B.G. (1999) Fra englevagt til englevinger. In: Myte, magi og mirakel i møte med det moderne, Pax, Oslo.

[16] Gustavsson, A. (2011) Cultural Studies on Death and Dying in Scandinavia. Novus, Oslo.

[17] Konrad, K. (1994) Die Wiederkehr der Engel. In: Religion in Everyday Life, Almqvist \& Wiksell International, Stockholm.

[18] Margry, P.J. and Sanchez-Carretero, C., Eds. (2011) Grassroots Memorials: The Politics of Memorializing Traumatic Death. Berghahn Books, Oxford, New York.

[19] www.tillminneav.se/showPage.php?id=.344

[20] www.tillminneav.se/showPage.php?id=34 
Scientific Research Publishing (SCIRP) is one of the largest Open Access journal publishers. It is currently publishing more than 200 open access, online, peer-reviewed journals covering a wide range of academic disciplines. SCIRP serves the worldwide academic communities and contributes to the progress and application of science with its publication.

Other selected journals from SCIRP are listed as below. Submit your manuscript to us via either submit@scirp.org or Online Submission Portal.
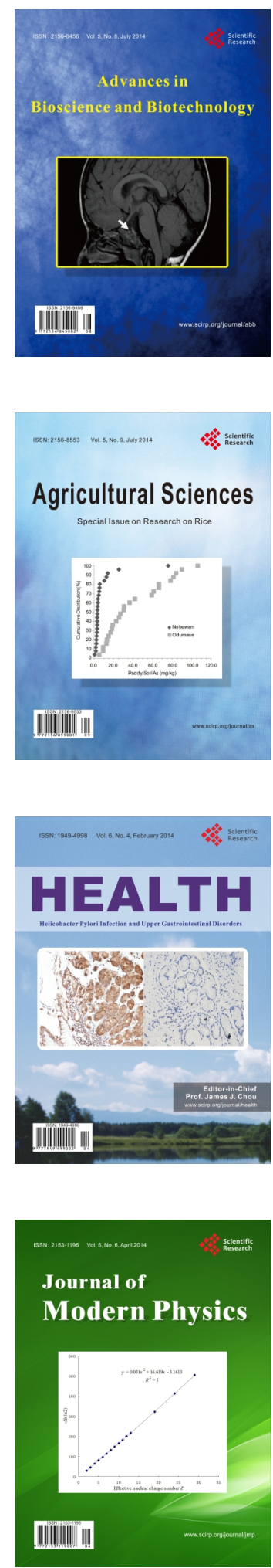
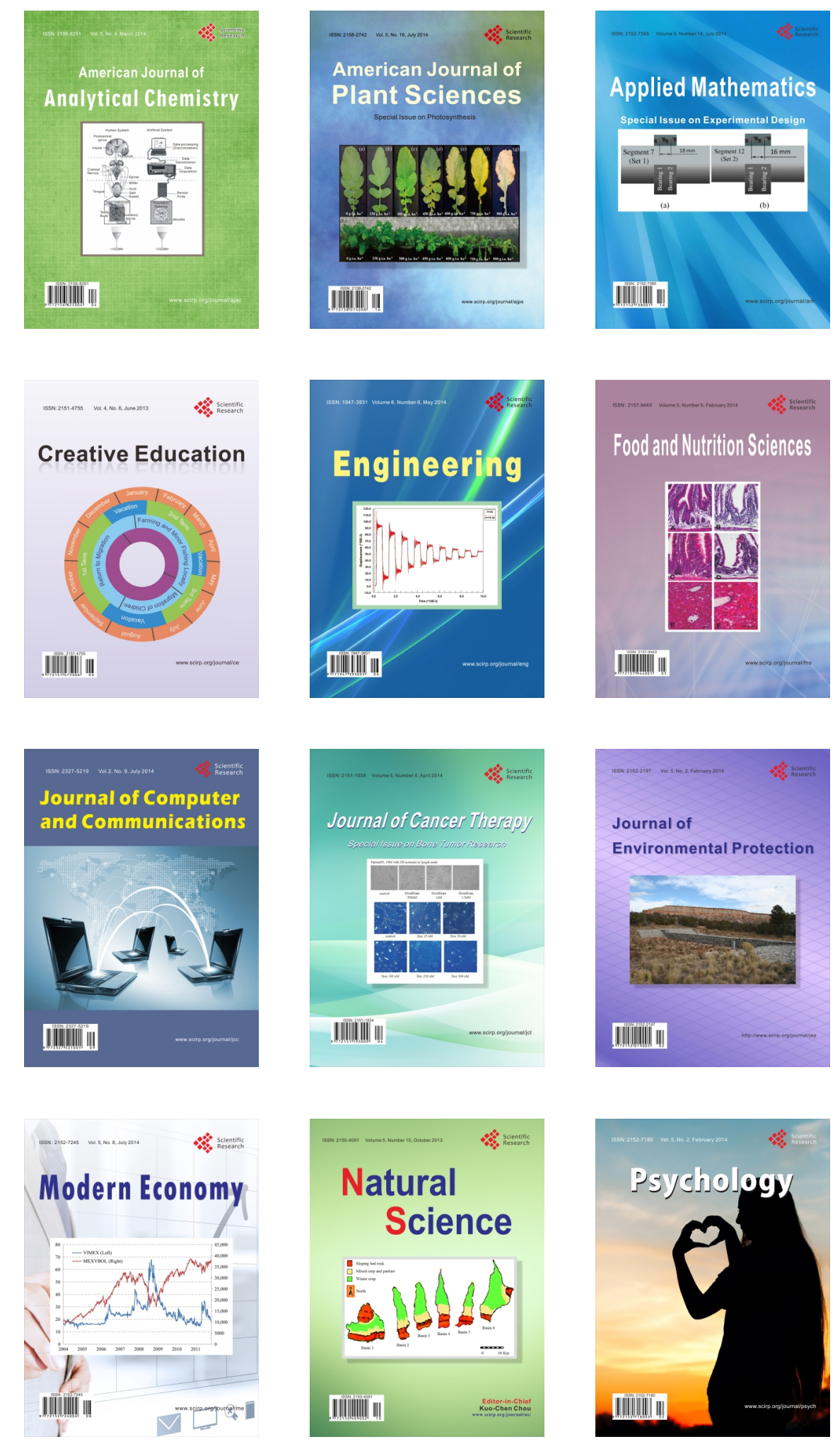